\title{
Wokół współczesnej sztuki dramatycznej w Polsce
}

\begin{abstract}
Hendrykowski Marek, Wokół współczesnej sztuki dramatycznej w Polsce [Around contemporary Polish dramatic art]. „Przestrzenie Teorii" 23. Poznań 2015, Adam Mickiewicz University Press, pp. 255-266. ISBN 978-83-232-2920-9. ISSN 1644-6763. DOI 10.14746/pt.2015.23.15.
\end{abstract}

Polish contemporary drama (which is represented by a range of authors, from Tadeusz Różewicz and Sławomir Mrożek, Janusz Głowacki, Wiesław Myśliwski, Eustachy Rylski, Marek Koterski and Tadeusz Słobodzianek to Przemysław Wojcieszek, Michał Walczak, Piotr Tomaszuk, Tomasz Man and Dorota Masłowska) seems to be an integral part and a special, local manifestation of profound changes that have taken place in the European and American drama of the $20^{\text {th }}$ and $21^{\text {st }}$ centuries. Samuel Beckett, Eugène lonesco, Tennessee Williams, Harold Pinter, John Osborne and Edward Albee influenced Polish dramaturgy, i.e. its general concept and philosophy, in many ways. They were pioneers and patrons of this transformation, just as Miron Białoszewski was in Poland. New Polish dramaturgy continues to go in this direction while looking for modern means of theatrical expression. Marek Hendrykowski examines and describes twenty-one contemporary dramas that are collected in two volumes titled Trans/formacja. Dramat polski po 1989 roku [Trans/formation: An Anthology of Polish Contemporary Drama after 1989], which were edited by Jacek Kopciński. The author of this article searches for features and "common places" (loci communes) that are typical of this form of art.

\section{Dramat jako scenariusz, scenariusz jako dramat}

Splot powiązań łączących polski dramat po roku 1989 z polskim kinem stanowi intrygujący fenomen kulturowy. Choć dzisiejszy teatr miewa swoje siedziby przeważnie przy innych ulicach niż kino, dystans, jaki je dzieli, rozciaga się mimo wszystko w granicach tej samej topografii i przestrzeni kulturowej. Jak daleko stąd, jak blisko - można by powiedzieć, przywołując tytuł pamiętnego filmu Tadeusza Konwickiego z początku lat siedemdziesiątych. Z jednej strony, obie te dziedziny twórczości bardzo wiele dzieliło i nadal dzieli. $Z$ drugiej, okazuje się, że łączy je intrygująca zbieżność: dramatis personae, tematów, form, sytuacji dramatycznych i analogicznych sposobów autorskiego widzenia otaczającej nas rzeczywistości społecznej. 
$\mathrm{Na}$ pytanie, czy lepsza jest obecnie kondycja artystyczna rodzimego teatru, czy też przeciwnie naszego kina, odpowiedź wydaje się oczywista. Po latach permanentnej posuchy i nieurodzaju polska sztuka filmowa odradza się, czego przejawem najważniejszym są zarówno jej międzynarodowe laury, jak coraz lepsze wyniki frekwencyjne w ostatnich kilku sezonach. Odzyskanie zainteresowania widowni, przy wszystkich minusach, słabościach i ułomnościach dzisiejszej produkcji filmowej w Polsce, uważam za niekwestionowany sukces rodzimej kinematografii. Ludzie znów zaczęli chętnie chodzić na polskie filmy.

$\mathrm{W}$ odniesieniu do kina, ale także w stosunku do teatru ów wzrost zainteresowania dotyczy, rzecz znamienna, nie tylko głównego nurtu, lecz także pewnej liczby produkcji offowych. Off prowokuje centrum, więcej, zdobywa je. Koterski, Strzępka, Demirski, Augustynowicz, Lupa, Warlikowski, Jarzyna, Klata, Grzegorzek, Wojcieszek, Szumowska, Glińska, Barczyk i inni - potrafią poruszać widza i wytrącać go z obojętności. Stereotyp niepokornego artysty, który w swej twórczości odrzuca wszystko, co dostrzega i znajduje $\mathrm{w}$ swym otoczeniu, jest dzisiaj podstawowym instrumentem funkcjonowania zarówno rodzimego młodego teatru, jak i filmu.

Off okazuje się czymś więcej niż marginesem: staje się środowiskiem i ostoją niepokornych. Odbierzcie im poczucie, że tworzą sztukę offową, a natychmiast runie cała ideologia w stereotyp ten wpisana. Niepokorny autor dramatyczny jak tlenu potrzebuje do oddychania na co dzień poczucia, iż to, co robi, należy do offu. W naszych, i nie tylko naszych, warunkach zjawiskiem charakterystycznym jest od lat nie sam off jako opozycja teatru instytucjonalnego, lecz off jako integralna część teatralnego mainstreamu.

Jeśli na użytek niniejszego studium przyjąć formułę, iż zarówno polski film współczesny, jak i młody dzisiejszy dramat i teatr eksponują potrzebę konfrontacji estetyki i sztuki z dzisiejszymi przemianami dokonującymi się w kulturze i w życiu społecznym, można mówić o istotnym powinowactwie obu dziedzin twórczości.

\section{Antologia, jakiej nie było}

Rzecz powstała w latach 2012-2014 pod auspicjami ministra nauki i szkolnictwa wyższego w ramach programu pod nazwą „Narodowy Program Rozwoju Humanistyki”. Antologia polskiego dramatu współczesnego, jaką niedawno otrzymaliśmy, jest przedsięwzięciem pod każdym 
względem unikatowym, bez precedensu na gruncie naszej nauki o teatrze. Ostateczny efekt pracy warszawskich dramatologów pracujących pod kierunkiem prof. Jacka Kopcińskiego stanowią dwa pięknie wydane i opracowane opasłe tomy. Pierwszy z nich liczy blisko tysiąc stron, drugi - „zaledwie” osiemset. Ich wydawca jest renomowane Wydawnictwo Instytutu Badań Literackich PAN w Warszawie, które dołożyło wszelkich starań i dochowało należytej staranności, aby doprowadzić tę publikację do znakomitego kształtu.

Antologia Trans/formacja. Dramat polski po 1989 roku nie jest bynajmniej rutynową reedycją zbioru tekstów dwudziestu jeden najbardziej reprezentatywnych i znaczących sztuk minionego ćwierćwiecza. Nie o to w tym wszystkim chodziło i nie same teksty dramatyczne (wcześniej przecież publikowane najczęściej na łamach nieocenionego w swych zasługach miesięcznika „Dialog”) tworzą ową antologię. Jej niezwykle cenna wartość dodana polega na scaleniu owego fenomenu w jedno, a także na stworzeniu swoistego Who Is Who polskiego dramatopisarstwa doby obecnej.

Nie wiesz, kto to Lidia Amejko, kim jest Tomasz Man, kto kryje się pod pseudonimem Johann Keevus, a kto występuje pod pseudonimem Art Grabov, kto napisał sztukę Między nami dobrze jest, a kto dwie sztuki telewizyjne o śmierci: Solo i Kwintet? - Nie szkodzi. Teraz najróżniejsze poszukiwane przez ciebie odpowiedzi mieszczą się pod tym samym - natychmiast dostępnym - adresem. Wszystkie te szczegółowe informacje, a także bezlik innych można od niedawna znaleźć w jednym wspólnym miejscu, po prostu zaglądając do wspomnianych dwóch tomów.

Gwoli prawdy, unikatowy charakter antologii Kopcińskiego nie bierze się stąd, iż nikt wcześniej nie opublikował u nas wyboru polskich sztuk dramatycznych. Owszem, zdarzały się przed nią inne, nawet dość liczne. Wymieńmy przykładowo: Pokolenie Porno $i$ inne niesmaczne utwory teatralne. Antologia najnowszego dramatu polskiego w wyborze Romana Pawłowskiego (red. H. Sułek, Kraków 2003), Echa, repliki, fantazmaty. Antologia nowego dramatu polskiego (red. M. Sugiera, A. Wierzchowska-Woźniak, Kraków 2005), Made in Poland. Dziewięć sztuk teatralnych $z$ Polski (również w wyborze R. Pawłowskiego, red. H. Sułek, Kraków 2006) oraz indywidualna antologia twórczości dramatycznej Marka Koterskiego Dzień świra i inne monologi Adasia Miauczyńskiego na jedna lub więcej osób (Izabelin 2012).

Wydania książkowe i antologie nowej dramaturgii pełnią we wszystkich tych przypadkach istotną funkcję kulturotwórczą jako swoiste wyróżnienie tej formy twórczości awansowanej do rangi samoistnego tytułu książkowego, na dodatek jeszcze prezentowanego w szacownych oficy- 
nach i edycjach, a w paru przypadkach także w naukowym opracowaniu krytycznym. Antologia sztuk teatralnych udostępniona w starannie opracowanej formie książkowej staje się tą drogą przejawem kulturowego pietyzmu i rodzajem symbolicznej apretury dla twórczości dramatycznej w kulturze współczesnej.

\section{Pasaż romantyczny}

Aby właściwie ocenić i zmierzyć wartość opracowanej przez Jacka Kopcińskiego - przy współpracy edytorskiej Grzegorza Wroniewicza (tom pierwszy) i Blanki Mieszkowskiej (tom drugi) - antologii Trans/formacja. Dramat polski po 1989 roku, spróbujmy wyobrazić sobie coś, co nigdy się nie zdarzyło.

Oto mamy rok 1850 i hipotetyczny antologista mieszkajacy w równie hipotetycznym dzisiaj Paryżu czy Warszawie przystępuje do opracowania edycji polskich sztuk dramatycznych ostatnich kilku dekad: mieszczących się w umownym przedziale czasowym: od 1820 do 1850 roku.

Mowa tu nie o jakimkolwiek przypadkowo wybranym okresie, lecz o złotej epoce polskiego dramatu romantycznego: zarówno emigracyjnego, jak i krajowego. To ostatnie zastrzeżenie okazuje się niezmiernie ważne, bowiem linia graniczna naszej dramaturgii tworzonej zarówno w kraju, jak i na emigracji dzieli w tym wypadku nie tylko poszczególnych dramatopisarzy i napisane przez nich wtedy sztuki, ale niekiedy przebiega również - w sposób doprawdy kuriozalny - wewnątrz jednego utworu (casus Mickiewiczowskich Dziadów wileńsko-kowieńsko-drezdeńskich).

Cóż to była za wspaniała epoka! Niekończące się pasmo arcydzieł dramatycznych. Najpierw Dziady Mickiewicza (1822-1832), ustanawiające całkiem nowy wzorzec rodzimego dramatopisania. Oprócz nich fenomenalna seria sztuk Słowackiego: Kordian (1833-1834), Balladyna (1834-1839), Lilla Weneda (1839-1840), Horsztyński (1835), Sen srebrny Salomei (1843-1844), Fantazy (1844-1845). Dalej, kapitalne „krajowe” komedie Fredry, wśród nich: Zemsta (1832-1838), Śluby panieńskie (1832), Pan Jowialski (1832), Dożywocie (1834-1835) i kolejne dwa arcydramaty polskiego romantyzmu emigracyjnego: najpierw Nie-Boska komedia (1833-1835), a potem wiedeńsko-paryski Irydion (1835-1836) Krasińskiego. W sumie unikat na skalę jeśli nie światową, to z pewnością europejską. Mickiewicz, Słowacki, Fredro, Krasiński - tworzą wspólnie niezrównany w swej klasie absolutny wunderteam, bez precedensu w polskiej literaturze dramatycznej. 
Powróćmy jednak do specyfiki zadania, jakie stanęłoby przed hipotetycznym dziewiętnastowiecznym antologistą rodzimej dramaturgii romantycznej. Zapewne sporo byśmy dzisiaj dali, mowa tu głównie o historykach literatury i badaczach polskiego dramatu, aby na potrzeby tej nieistniejącej antologii autor dramatyczny Adam Mickiewicz scalił w autorskim kształcie no varietur Dziady, a Juliusz Słowacki sporządził na użytek tego samego krytycznego wydania własną wersję Kordiana wyposażoną w odautorskie objaśnienie pierwotnej koncepcji swego dramatu ${ }^{1}$. Niestety, nic z tych rzeczy. Nie stało się, nie jest i nigdy nie będzie. Dlatego właśnie można tylko pozazdrościć, kiedy czyta się w redakcyjnym objaśnieniu Jacka Kopcińskiego zamieszczonym na końcu Dnia świra Marka Koterskiego następujący passus: „Zgodnie z wolą Autora nie ingerowano w interpunkcję i zachowano specyficzny układ graficzny tekstu. Poprawiono jedynie oczywiste błędy druku [tekst ukazał się na podstawie wydania Dzień świra i inne monologi Adasia Miauczyńskiego na jedna lub więcej osób, Świat Literacki, Izabelin 2002 - przyp.- M.H.] i wprowadzono, po konsultacji z Autorem, drobne zmiany tekstowe"2.

Rzecz cała nie w takiej czy innej obróbce filologicznej tych tekstów, lecz w tym, że antologia sporządzona przez Jacka Kopcińskiego składa się $\mathrm{w}$ sumie na intrygująco pokazany całościowy obraz ponadjednostkowej poetyki i estetyki, jaką operuje współczesna polska dramaturgia. Nie mogąc zamieścić w obu tomach wszystkiego, twórca antologii zdecydował się wybrać utwory nie tyle najlepsze (cokolwiek miałoby to znaczyć), ile najbardziej reprezentatywne pod względem ich dramatyczno-teatralnej i socjokulturowej charakterystyki. I tak nakreślone zadanie badawczo-edytorskie, wraz z paruosobowym zespołem pomocników wykonał z całą starannością w sposób nad wyraz rzetelny.

\section{Drugie tyle nazwisk}

Nowa dramaturgia obejmuje swym zasięgiem pokaźną grupę piszących. Krytyk antologii Trans/formacja. Dramat polski po 1989 roku mógłby w pierwszym rzędzie zakwestionować obecność w niej sztuk zaledwie dwudziestu jeden wyselekcjonowanych autorów. Lista pominiętych w niej dramatopisarzy obejmuje przecież co najmniej drugie tyle nazwisk. Aby się o tym przekonać, wystarczy przywołać długi szereg innych. Są wśród nich przykładowo: Paweł Sala (Zagubiona epoka, Mortal Kombajn,

1 Zob. J. Maciejewski, „Kordian” - trylogia dramatyczna, Poznań 1961; tenże, „Kordian” Juliusza Stowackiego, Warszawa 1976.

2 Trans /formacja. Dramat polski po 1989 roku, wybór i wstęp J. Kopciński, t. 1, Warszawa 2012, s. 919. 
Trzecie przyjście, Gang bang albo Syndrom Sztokholmski, Spalenie matki, Od dziś będziemy dobrzy), Eustachy Rylski (Chtodna jesień, Wilk kazański, Zapach orchidei, Netta, Dzień podróżny), Tadeusz Słobodzianek (Turlajgroszek, Sen pluskwy, Nasza klasa, Prorok Ilja, Śmierć proroka), Monika Powalisz (Córka myśliwego albo polakożerczyni), Buba Łazuch-Łazanka (Do re my kla: Wprostmoderna tratata $w$ roszku ma zaszczyt zastawić sie tytułem), Robert Kucharski (Co mamy dziś w programie?), Marek Kochan (Argo. Misterium komercyjne z udziałem Krzysztofa Kamila, Hollyfood), Andrzej Pieczyński (Sierota), Władysław Zawistowski (Witajcie $w$ roku 2002. Sztuki telewizyjne), Paweł Mossakowski (Dom pełen miłości), Grzegorz Wróblewski (Przesilenie), Szymon Wróblewski (Powierzchnia), Jarosław Wiśniewski (Asinara, Diabeł mieszka pod 104-tym, Czekając na życie), Michał Bajer (Strefa dziatań wojennych), Mariusz Bielak (Copywriter), Ingmar Villqist (Kostka smalcu z bakaliami, Oskar $i$ Ruth, Noc Helvera, Złote wesele, Miłość w Königshütte), Andrzej Saramonowicz (Testosteron), Grzegorz Nawrocki (Mikrodramatyczne etiudy na tematy prasowe, Młoda śmierć), Dana Łukasińska (Agata szuka pracy), Małgorzata Owsiany (Zastępstwo), Jarosław Kisieliński (Akt zgonu, Larwy, czyli Święty owoc kolaboracji), Władcy ognia), Paweł Jurek (Pokolenie Porno, Urojenia /wersja 01/, /Nie/ pobiegne za toba), Jakub Sut (www.dom.pl), Michał Walczak (Piaskownica, Kopalnia, Podróż do wnętrza pokoju, Dziwna rzeka, Całe życie Jarosława, Miasteczko G., To nie jest kraj dla wielkich ludzi, Ojciec polski), Marek Modzelewski (Koronacja), Paweł Demirski (From Poland with love), Joanna Owsianko (Tiramisu), Jan Klata (Uśmiech grejpruta, Weź, przestań), Maciej Kałach (Symulakrum), Krzysztof Rudowski (Cz@t) i in.

Czy zestawienie powyższe w konsekwencji prowadzi nas do wniosku, że istnieje jakaś inna - alternatywna wobec przedstawionej na kartach Trans/formacji, może bardziej reprezentatywna - antologia naszego dramatu współczesnego? Niekoniecznie. Podobne domniemanie trudno byłoby uznać za uprawnione, choć tytułów i autorów (niekiedy dobrze znanych), jak widać, nie brakuje. Sprawą o kluczowym znaczeniu nie jest tu wybór i pominięcie tych czy innych sztuk i dramaturgów, lecz jakość i reprezentatywność danego zestawu tekstów z punktu widzenia o wiele szerszej całości, do jakiej one należą.

\section{Katalog bez końca}

Dość obfita już w obecnej chwili literatura przedmiotu traktująca o polskiej dramaturgii współczesnej zawiera w sobie wiele szczegółowych rozważań i interesujących propozycji wymodelowania właściwych jej cech 
wspólnych. Piszący o niej wielokrotnie zwracali uwagę na takie powtarzalne wątki, motywy i wyróżniki tematyczne, jak: alienacja i wzajemna obcość postaci, tematyka rozpadu więzi społecznych, atrofia wyższych wartości, agresja występująca $\mathrm{w}$ relacjach międzyludzkich, motyw termitiery i życia odartego z prywatności, egzystencja w beznadziei codzienności, degradacja form człowieczeństwa, ukazywanie traum i neuroz bohaterów, syndrom psychofizycznego uwięzienia w klatce czasoprzestrzeni, dezintegracja jednostki, rodziny i zbiorowości.

$\mathrm{Na}$ liście cech wspólnych przypadających w udziale naszej dramaturgii tworzonej przez kilkudziesięciu autorów na przestrzeni ostatniego ćwierćwiecza znajdują się ponadto: pozaartystyczne zaangażowanie twórców, odrzucanie przez dramatopisarzy tradycyjnych wzorców „,sztuki dobrze zrobionej", cytaty z codzienności, brutalizmy, anty-estetyka szoku i, last but not least, niemal obsesyjnie podejmowana dekonstrukcja rozmaitych iluzji dostarczanych człowiekowi przez medialną rzeczywistość zastępczą.

O ile wyznaczniki wcześniej wymienione nie są czymś specjalnie oryginalnym - można je bowiem bez trudu znaleźć i wskazać w klasycznych sztukach poprzedników, między innymi u Ibsena i Strindberga, a potem w procesie ewolucji dwudziestowiecznego dramatu: od jego prekursorów Jarry'ego (Król Ubu czyli Polacy, 1896), Wedekinda (Puszka Pandory, 1904, Cenzura, 1908) i Witkacego (Karaluchy, 1893, Nowa homeopatia $z \nmid a, 1918)$ po Sartre'a, Gombrowicza i Różewicza, zwłaszcza zaś w sztukach Ionesco i Becketta spod znaku teatru absurdu - o tyle ostatni ze wskazanych wyznaczników wydaje się swoisty. Nie tylko rzutuje w zasadniczy sposób na ich estetykę, ale i zawiera w sobie znaczny potencjał interpretacyjny: zarówno w kwestii mowy i zachowań postaci, jak i wówczas, gdy pada pytanie o miejsce nowej dramaturgii wśród współczesnych form komunikowania i rolę, jaką ona dla siebie projektuje i usiłuje pełnić nie tylko w teatrze współczesnym, ale także w życiu społecznym.

Język artystyczny tych dramatów upatruje własnej oryginalności poza tradycyjnymi wyobrażeniami „sztuki” i „artyzmu” (oba cudzysłowy konieczne), dążąc przy tym w najciekawszych i najambitniejszych swych przejawach do generalnego zakwestionowania i odrzucenia panujących dotąd konwencji oraz form dramatycznego wyrazu wcześniej wykształconych. Rysuje się tutaj intrygujący wspólny mianownik twórczych poszukiwań łączący rodzimą dramaturgię współczesną z pewnym nurtem polskiego kina, występującym nie tylko w filmie fabularnym, ale również dokumentalnym. 


\section{Dramat jako zjawisko transmedialne}

Czy to dzieło przypadku, czy szersza prawidłowość, że w kinie polskim ostatniego ćwierćwiecza natrafiamy na tak wiele przejawów artystycznych filiacji filmu z nowym dramatem i teatrem? Niektórzy polscy reżyserzy filmowi - wymieniam w tym miejscu przykładowo nazwiska: Koterskiego, Marczewskiego, Bajona, Glińskiego, Jakimowskiego, Smarzowskiego, Grzegorzka, Szumowskiej, Sali, Piekorz, Wojcieszka, Barczyka - czerpali i nadal czerpią pełnymi garściami z repertuaru chwytów charakterystycznych dla poetyki współczesnego dramatu i teatru. Twórczość wymienionych reżyserów stanowi w niektórych przypadkach organiczną jedność transmedialnego przenikania się i przechodzenia jednego $\mathrm{w}$ drugie.

U początków występowania tego procesu mamy do czynienia jedynie z sygnałami jego prekursorskiej obecności w danym tu i teraz. To zalążkowe stadium procesu transmisji wartości estetycznych między mediami zaznaczyło się w polskim teatrze i filmie, wówczas jeszcze ledwie symptomatycznie, mniej więcej 20-25 lat temu. W miarę swego pogłębiania się i poszerzania zjawisko transmedialności nowej formuły dramatu stawało się znacznie bardziej wyraziste: dostarczając naszemu życiu artystycznemu coraz więcej przejawów odmiennego niż dawniej, integralnego traktowania sztuk. W istocie mamy dzisiaj do czynienia $\mathrm{z}$ nowoczesną odmianą correspondance des arts, a w jej ramach z rosnącą potrzebą wypróbowywania i kreatywnego przepracowywania treści, tematów i motywów ukazywanych w różnych formach sztuki.

Aby zdać sobie sprawę z powszechności tego fenomenu, warto przywołać takie filmy, jak: Bal na dworcu w Koluszkach, Sauna, Engagement i Portret męski we wnętrzu Filipa Bajona, niedoceniony w swoim czasie Czas zdrady Wojciecha Marczewskiego, Rozmowa z człowiekiem z szafy, Królowa aniołów i Jestem twój Mariusza Grzegorzka, Patrzę na ciebie, Marysiu, Nieruchomy poruszyciel, Italiani i Hiszpanka Łukasza Barczyka, Ono, 33 sceny z życia i W imię... Małgorzaty Szumowskiej, Gtośniej od bomb, Made in Poland, Sekret i Jak całkowicie zniknać Przemysława Wojcieszka, Zmruż oczy i Sztuczki Andrzeja Jakimowskiego, Aria Diva Agnieszki Smoczyńskiej, Pas de deux Kingi Lewińskiej, Matka Teresa od kotów Pawła Sali czy Dziewczyna z szafy Bodo Koxa.

O niektórych spośród wymienionych, jak choćby o Mariuszu Grzegorzku, należałoby wręcz mówić jako reżyserze w jednej osobie i w jednakowym stopniu: teatralnym, filmowym i telewizyjnym. Konsekwentnie 
rozwijana transmedialność tej twórczości stanowi bowiem nie jakiś modny akcent czy powierzchowną aplikację, lecz bardzo istotny wyróżnik indywidualnej estetyki inscenizowanych przez niego utworów. Podobną obserwację można poczynić i odnieść również do twórczości Małgorzaty Szumowskiej czy filmów Magdaleny Piekorz Pręgi i Zbliżenia.

Klasą dla siebie są w tym gronie dwaj inni wybitni reżyserzy. Pierwszym z nich jest Marek Koterski jako autor prekursorskiego Domu wariatów (1985!) i twórca takich pamiętnych filmów, jak: Dzień świra (2002), Wszyscy jesteśmy Chrystusami (2006) czy Baby sq jakieś inne (2011). Drugim - Wojciech Smarzowski jako twórca Wesela (2004), Domu złego (2009) i Pod Mocnym Aniołem (2014). Kunszt dramaturgiczny zarówno Koterskiego, jak i Smarzowskiego, każdy z nich na swój sposób, stanowi kapitalny przykład dojrzałego i niezmiernie świadomego aranżowania procesu korespondencji sztuk pomiędzy teatrem a filmem, i vice versa.

Jak wynika z powyższego dość pobieżnego zestawienia, polski Kammerspiel okazuje się fenomenem niezmiernie bogatym w wysokiej próby artystyczne dokonania.

$\mathrm{W}$ relacji polskiego kina $\mathrm{z}$ polskim dramatem i teatrem najbardziej zdumiewa jednak co innego, mianowicie: teatralizacja dokumentu. Chodzi o postępującą teatralizację filmu dokumentalnego w jego odmianie artystycznej. Dokument nasz przeszedł w ciągu ostatniego ćwierćwiecza znamienną metamorfozę. Dokonana już i nadal dokonująca się teatralizacja kina niefikcjonalnego sama w sobie zakrawa na przedziwny paradoks, a przecież jest ona faktem. Mam tutaj na myśli długi szereg takich dokumentów, jak: Wszystko może się przytrafić i Jak to się robi Marcela Łozińskiego, Siostry, Taka historia i Chemia Pawła Łozińskiego, Takiego pięknego syna urodziłam, Jakoś to będzie i Ucieknijmy od niej Marcina Koszałki czy dyptyk dramatyczny Marcela i Pawła Łozińskich: Ojciec $i$ syn w podróźy oraz Ojciec $i$ syn.

We wszystkich wymienionych tu filmach dostrzegalny jest nie tylko wpływ jednej dziedziny na drugą, ale także o wiele szerszy proces obustronnej wymiany inspiracji między teatrem a kinem. Tak pojęta twórcza wymiana stanowi cząstkę o wiele szerszego zjawiska transmedialności. Pora zapytać o jego roboczą definicję.

Transmedialność $\mathrm{w}$ znaczeniu przyjętym na użytek tego studium oznacza krążenie, przemieszczanie się i adaptację określonego zjawiska (w interesującym nas tutaj przypadku jest nim specyficzna formuła nowego dramatu), współobecnego w poszczególnych mediach i różnych obiegach danego systemu kultury. Rzecz nie tylko w swoistości danego medium. Gotowość twórczego zaadaptowania takiego zjawiska występu- 
jącego $\mathrm{w}$ różnych postaciach medialnych (teatr, kino, telewizja, sztuki plastyczne, muzyka, performance, sztuka sieci, internet itp.) staje się miarą żywotności formacji kulturowej, w której zjawisko owo występuje.

\section{Konkluzja}

Pora zmierzać ku końcowi zaprezentowanych wyżej rozważań na temat współczesnej polskiej dramaturgii. Bardziej ogólny wniosek, jaki się tutaj nasuwa, dotyczy przede wszystkim intrygującej kwestii jej wartości artystycznej, która - dość rzadko poruszana w licznych okazjonalnych omówieniach - nie jest bynajmniej zagadnieniem jednoznacznym ani oczywistym. Mamy tu do czynienia ze sztuką, czy jak kto woli pewną formą anty-sztuki, która niemal programowo odrzuca tradycyjne wyobrażenia „dobrze napisanego" dramatu scenicznego. Czy wobec tego należy pomijać milczeniem aksjologiczny wymiar tej twórczości związany z tradycją dramatu i teatru? Wprost przeciwnie, wymiar ten zasługuje jak najbardziej na uważne odczytanie i pogłębioną interpretację.

Nie sposób przy tym pominąć przejawów imitatorstwa, wtórności i swoistego epigonizmu. Nie dotyczy to twórców dramatycznych, takich jak: Koterski, Głowacki, Rylski czy Słobodzianek. Niestety, sporo powieleń i tandetnego naśladownictwa bywa za to u innych dramatopisarzy. W ich sztukach trudno odnaleźć coś autentycznie nowego. Za to niemało spotyka się niby nowego, czytaj: „nowego”. Pozór teatralnej nowości ostentacyjnie zastępuje nowość rzeczywistą. Poczynając od realiów świata przedstawionego budującego określony obraz współczesności, a kończąc na sposobie konstruowania postaci scenicznych.

Zastanawiające doprawdy, że w sztukach spod znaku nowej dramaturgii osoby dramatu pojawiają się nie jako ludzie, lecz najczęściej jako offowe indywidua. Autorzy traktują swoje postaci niczym ludzkie monady, nadając im na wyrost status bytów wyjątkowych: dziwolągów współczesnego społeczeństwa. Ich powierzchownie nakreślona typowość osiąga znaczenie jedynie referencyjne. Zamiast tego mamy do czynienia $\mathrm{z}$ panopticum dziwactw i galerią curiosów, a sytuacje dramatyczne rozgrywają się na wyobrażeniowej osi doskonale znanego modernistom konfliktu: odmieniec - filister. Niektórym z tych sztuk znacznie bliżej niż do Ionesco, Becketta czy Różewicza do Jana Augusta Kisielewskiego i jego młodopolskich dramatów: W sieci (1896) oraz Karykatury (1898).

Odpowiedź na kłopotliwe pytanie o oryginalność dokonań rodzimej dramaturgii ostatniego ćwierćwiecza okazuje się zatem odpowiedzią nie- 
jednoznaczną w swej wymowie. Część utworów dramatycznych napisanych w tym okresie niewątpliwie zasługuje na to, by mówić o ich oryginalnym wkładzie do rozwoju współczesnej twórczości dramatopisarskiej. Stanowczo jednak nie można tego powiedzieć o wielu innych. Niektórzy autorzy sztuk - dążąc za wszelką cenę do wykreowania całkiem nowej jakości teatralnej - mimowiednie popadali we wtórność. Wtórność owa nie dotyczy zamiarów (poetyka deklarowana), lecz osiągniętych efektów (poetyka zrealizowana danego utworu). Polega ona przede wszystkim na mozolnym wyważaniu drzwi i uwalnianiu przestrzeni dramaturgii dawno otwartych przez sztukę dwudziestowiecznego teatru. Z filozofią sztuki zadziwiająco bliską iluzjom i rozmaitym skandalizującym zabiegom przybyszewszczyzny.

Rezultat wielu z tych prób dramatycznych przedstawia się paradoksalnie. Zadekretowana $\mathrm{z}$ góry frontalna rozprawa $\mathrm{z}$ tradycją - wyrażająca się w próbach mniej lub bardziej ostentacyjnego odrzucenia tego wszystkiego, co już było - nie doprowadziła do powstania nowej jakości. Powołała za to do istnienia model dramatu na pozór wolny od wszelkich nawiązań do przeszłości, a $\mathrm{w}$ gruncie rzeczy uwikłany $\mathrm{w}$ paradygmat „nowej dramaturgii” (cokolwiek owo umowne pojęcie miałoby oznaczać). Nowe wyzwolenie polskiej współczesnej sztuki dramatopisarskiej w dość nieoczekiwany sposób przerodziło się w jej dramatyczno-teatralne zniewolenie.

Krytyka, jaką tutaj przeprowadzam, dotyczy nie samego dramatopisarstwa, lecz w pierwszym rzędzie obecnego stanu naszego teatru instytucjonalnego. To on bowiem generalnie przesądza w tym, co i jak jest wystawiane w rokrocznym repertuarze, rzutując siłą rzeczy na przyszły kształt tego wszystkiego, co się dla niego pisze. Artyzm dzisiejszej twórczości dramaturgicznej to nie dalszorzędny temat i niewart uwagi marginalny aspekt życia teatralnego jako szeroko pojętego zjawiska społecznego, lecz kwestia o znaczeniu zasadniczym dla jego oceny.

Nasza dramaturgia przełomu XX i XXI wieku obejmująca okres minionego ćwierćwiecza, łamiąc i odrzucając zastane kanony i wymierzając policzek zbiorowym nawykom, przyjętym normom i powszechnemu gustowi, siłą rzeczy wchodzi w konfrontację z bliższą i dalszą przeszłością polskiego i światowego dramatu. Ciekawe skądinąd, że swoje najlepsze owoce wydała ona nie przez całkowite odrzucenie tradycji dramatycznej i teatralnej, lecz w twórczo podjętym dialogu z nią. Owe kontynuacje przez zaprzeczenie okazują się bez porównania cenniejsze niż demonstracyjne désintéressement dla dorobku przeszłości, rzekomo całkiem nieprzydatnego nowej sztuce dramatu. 
Mimo iż nie stworzyła dotąd żadnego arcydzieła (choć ma na swoim koncie kilka sztuk wybitnych, ewentualnymi kandydatami do tego miana mogłyby być $\mathrm{w}$ moim przekonaniu cztery z nich: Chłodna jesień Eustachego Rylskiego, Dzień świra Marka Koterskiego, Czwarta siostra Janusza Głowackiego i Nasza klasa Tadeusza Słobodzianka), jako szersza całość okazuje się zjawiskiem na swój sposób doniosłym i znaczącym dla rodzimej kultury. Poświęcona prezentacji tej twórczości antologia Trans/formacja. Dramat polski po roku 1989 stanowi ważny krok w kierunku jej wnikliwszego rozpoznania. 